\title{
Intracranial Hemorrhage in a Pregnant Patient with COVID-19: A Case Report
}

\author{
Gebelikte COVID-19 ve Intrakraniyal Kanama: Bir Olgu Sunumu
}

\author{
(D) Metin Şentürk ${ }^{1}$, (D) Mustafa Cihangiroğlu²
}

${ }^{1}$ Kastamonu Training and Research Hospital, Clinic of Obstetrics and Gynecology, Kastamonu, Turkey

${ }^{2}$ Amasya University, Sabuncuoğlu Şerefeddin Training and Research Hospital, Clinic of Infectious Diseases and Clinical Microbiology, Amasya, Turkey

\section{Abstract}

Pregnancy reportedly increased the risk of intracranial hemorrhage (ICH), and Coronavirus disease-2019 (COVID-19) has been found to be an associated factor. We report the case of a 26-year-old pregnant woman who was admitted to our hospital with a chief complaint of fatigue; she was diagnosed with COVID-19 and later developed ICH after cesarean section (C/S) delivery. The patient was tested for COVID-19 as her husband tested positive for it. After COVID-19 diagnosis, labor induction was decided due to amniorrhexis. Despite eight hours of labor induction, owing to the asynclitic presentation of the fetus, vaginal delivery did not progress; therefore, a $\mathrm{C} / \mathrm{S}$ was performed. The patient gave birth to a healthy baby, and favipiravir treatment was initiated. On day nine of hospitalization, she complained of nausea and headache. Brain computed tomography revealed an intraparenchymal hematoma. The patient did not have any risk factors, except pregnancy. The hematoma was removed, and hemorrhage was resolved; however, a brain edema developed. After dexamethasone and mannitol treatment, her condition improved and she was transferred to the clinic. In conclusion, ICH can be observed in the postpartum period in a pregnant patient with COVID-19 with no risk factors other than pregnancy. Keywords: COVID-19, intraparenchymal hematoma, pregnancy, intracranial hemorrhage

\section{Öz}

Gebeliğin intrakraniyal kanama (IKK) riskini artırdığı ve COVID-19'un İKK ile ilişkili bir faktör olduğu bildirilmektedir. Bu çalışmada hastanemize yorgunluk şikayeti ile başvuran 26 yaşındaki gebe, COVID-19 tanısı almış ve sezaryen doğum sonrası İKK gelişen bir olgu sunulmuştur. Eşinin COVID-19 pozitif olması sebebiyle hasta COVID-19 için test edilmiştir. COVID-19 tanısı konulduktan sonra amnioreksis nedeniyle hastada doğum indüksiyonuna karar verilmiştir. Sekiz saatlik doğum indüksiyonuna rağmen ve bebeğin asenkron prezentasyonu sebebiyle doğum gerçekleşmemiş ve hastaya sezaryen uygulanmıştır. Hasta sağlıklı bir bebek dünyaya getirmiş ve favipiravir tedavisi başlanmıştır. Yatışının dokuzuncu gününde hastanın mide bulantısı ve baş ağrısı yakınmaları ortaya çıkmıştır. Beyin tomografisinde intraparankimal hematom gözlemlenmiştir. Hastanın gebelik dışında komorbid risk faktörü bulunmamaktaydı. Hematomun temizlenmesi sonunda kanama düzelmiştir ancak beyin ödemi gelişmiştir. Deksametazon ve mannitol tedavisi sonrası hastanın durumu düzelmiş ve kliniğe sevk edilmiştir. Sonuç olarak, gebelik dışında risk faktörü olmayan gebe bir COVID-19 hastasında doğum sonrası dönemde IKK görülebilmektedir.

Anahtar Kelimeler: COVID-19, intraparankimal kanama, gebelik, intrakraniyal kanama

Cite this article as: Şentürk M, Cihangiroğlu M. Intracranial Hemorrhage in a Pregnant Patient with COVID-19: A Case Report. Mediterr J Infect Microb Antimicrob. 2021;10:40. 


\section{Introduction}

The incidence rate of cerebrovascular event (CVE) in patients with Coronavirus disease-2019 (COVID-19) has been reported to be between $0.7 \%$ and $1.2 \%{ }^{[1]}$. The possible difference in CVE incidence among patients with COVID-19 may be because of factors such as age and male sex and the presence of comorbidities such as hypertension and diabetes mellitus ${ }^{[2,3]}$. Anticoagulants that are used to treat COVID-19 may influence the risk of intracranial hemorrhage $(\mathrm{ICH})$, and the type and dose of anticoagulants used may explain the difference in CVE incidence ${ }^{[4]}$.

Pregnancy has been reported to increase the risk of $\mathrm{ICH}$, and this event is frequently encountered in the postpartum period; 7.1\% of all pregnancy-related maternal mortalities are caused by $\mathrm{ICH}^{[5]}$. Coronavirus disease-2019-associated coagulopathies have been implicated in pregnancy ${ }^{[6]}$. Therefore, pregnant women with COVID-19 may have higher risk of ICH.

Herein, we present the case of a patient with COVID-19 who developed $\mathrm{ICH}$ in the postpartum period.

\section{Case Report}

A 26-year-old patient at 38 weeks of gestation was admitted to our emergency department with a chief complaint of fatigue. She was hospitalized in our clinic as her husband was diagnosed with COVID-19, and she also tested positive for COVID-19 in the polymerase chain reaction test. On day two of her admission, owing to amniorrhexis, labor induction was decided after appropriate delivery room conditions were provided. Despite eight hours of labor induction for vaginal birth, the labor did not progress; because of the asynclitic presentation of the baby, cesarean section (C/S) was performed.

A healthy single child with 9/9 APGAR score which is assessed in turns of Appearance, Pulse, Grimace, Activity, and Respiration of fetus was delivered, the mother was transferred to the postoperative follow-up unit, and postoperative ceftriaxone (2x1) was started with the recommendation of the infectious diseases doctor, paracetamol $(3 \times 500)$ and low molecular weight heparin (LMWH) $4000 \mathrm{IU}$ once a day at the postpartum $12^{\text {th }}$ hour. LMWH was used until intracranial bleeding occurred. Bilateral lung computed tomography performed on postoperative day 1 revealed an increase in the dependent density at the posterior part of the lungs. Detection of peripherally located focal patched ground-glass density areas in the lungs supported the diagnosis of COVID-19 pneumonia (Figure 1). The patient was orally administered with $2 \times 1600-\mathrm{mg}$ favipiravir on postoperative day 1 and $2 \times 600-\mathrm{mg} /$ day favipiravir on the following days; subcutaneous low-molecular-weight heparin (4000 IU/day) treatment was initiated. Methylprednisolone $(2 \times 80 \mathrm{mg})$ was intravenously administered because of persistent complaints, and C-reactive protein levels were elevated on postoperative day two (Table 1).

A neurology consultation was requested for the patient; she had severe headache and nausea on day nine of hospitalization (seven days after the $\mathrm{C} / \mathrm{S}$ ) and had a Glasgow Coma Scale (GCS) score of 15. The patient had epileptic seizures during brain computed tomography, and the GCS score dropped to four. She was then intubated after midazolam administration. The tomography revealed an intraparenchymal hematoma (IPH) of approximately $4 \times 2 \mathrm{~cm}$ in the periventricular white matter of

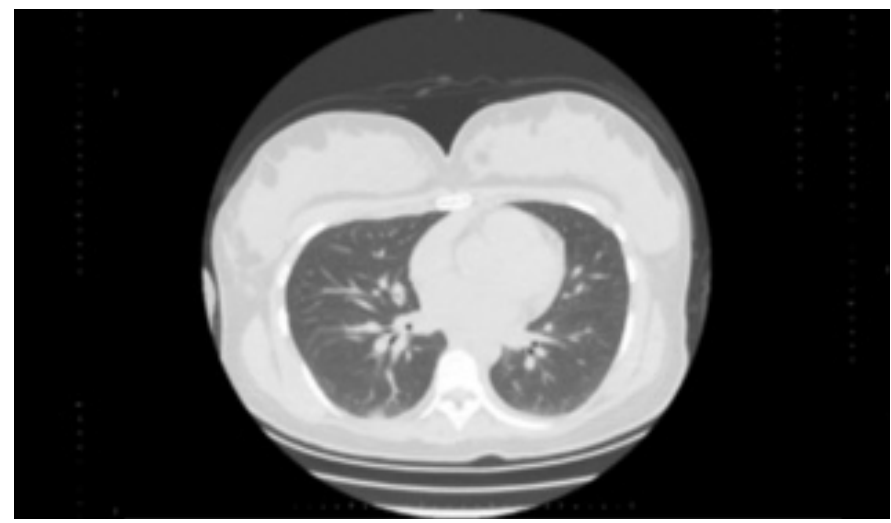

Figure 1. Areas of involvement on chest computed tomography

\begin{tabular}{|c|c|c|c|c|c|c|c|}
\hline Day & $\begin{array}{l}\text { Blood pressure } \\
\text { (systolic/diastolic; } \mathrm{mmHg} \text { ) }\end{array}$ & $\begin{array}{l}\text { WBC 3.5-10.5 } \\
\left(10^{3} / \mu \mathrm{L}\right)\end{array}$ & $\begin{array}{l}\text { LYMPH 0.9-2.9 } \\
\left(10^{3} / \mu \mathrm{L}\right)\end{array}$ & $\begin{array}{r}\text { CRP 0-5 } \\
(\mathrm{mg} / \mathrm{dL})\end{array}$ & $\begin{array}{l}\text { D-dimer } \\
0-0.55 \\
\text { (ng/mL) }\end{array}$ & $\begin{array}{l}\text { Ferritin } \\
11-307 \\
(\mathrm{ng} / \mathrm{mL})\end{array}$ & $\begin{array}{l}\text { LDH } \\
0-248 \\
\text { (U/L) }\end{array}$ \\
\hline COVID-19 day 1 & $100 / 60$ & 9.20 & 1.00 & 5.31 & 0.90 & 37.6 & 313 \\
\hline $\mathrm{C} / \mathrm{S}$ preoperative day & $110 / 80$ & 8.44 & 1.36 & 10.27 & 2.21 & 46.4 & 183 \\
\hline $\mathrm{C} / \mathrm{S}$ postoperative day 1 & $120 / 80$ & 8.93 & 1.53 & 13.99 & 2.41 & 52.9 & 282 \\
\hline Brain hemorrhage day 1 & $160 / 90$ & 15.90 & 1.97 & 11.43 & 3.08 & 103.5 & 310 \\
\hline Brain hemorrhage day 3 & $120 / 60$ & 10.34 & 1.31 & 26.45 & 3.19 & 122.8 & 302 \\
\hline Brain hemorrhage day 5 & $115 / 75$ & 9.45 & 1.24 & 32.13 & 4.22 & 249.4 & 302 \\
\hline Brain hemorrhage day 7 & $120 / 80$ & 12.35 & 0.99 & 12.69 & 4.84 & 384.6 & 303 \\
\hline
\end{tabular}

C/S: Cesarean section, CRP: C-reactive protein, LDH: Lactate dehydrogenase, LYMPH: Lymphocyte count, WBC: White blood cell count, COVID-19: Coronavirus disease-2019 
the right frontal lobe and decreased density compatible with edema in its proximity. The hematoma expanded to the right lateral ventricle, and enlargement in the ventricular system and hyperdensities of hemorrhage products within the entire ventricular area were observed. Approximately $6 \mathrm{~mm}$ of left side shift was detected in the midline structures. Densities of other cerebral parenchymal areas, brain stem formations and cerebellum in the posterior fossa, and skull base and calvarium were normal (Figure 2). The patient immediately underwent surgery; the hematoma was removed, and a shunt was placed.

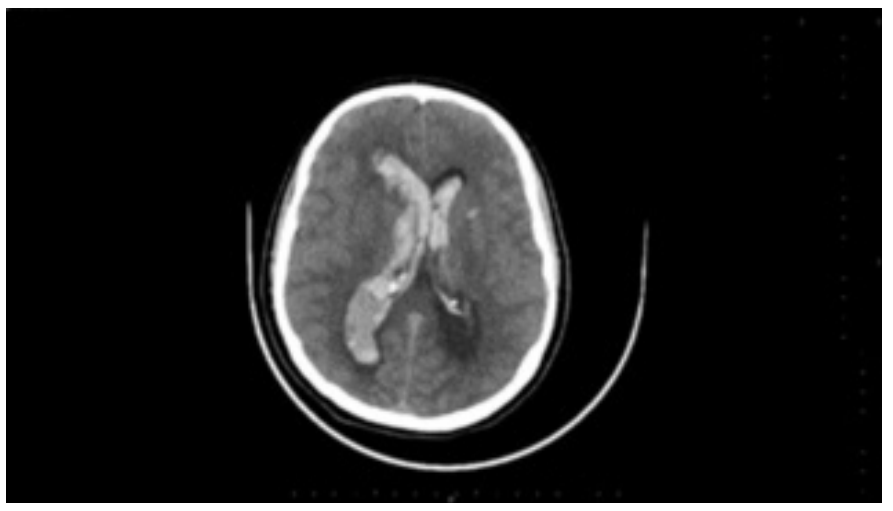

Figure 2. Brain computed tomography image showing intracranial hemorrhage

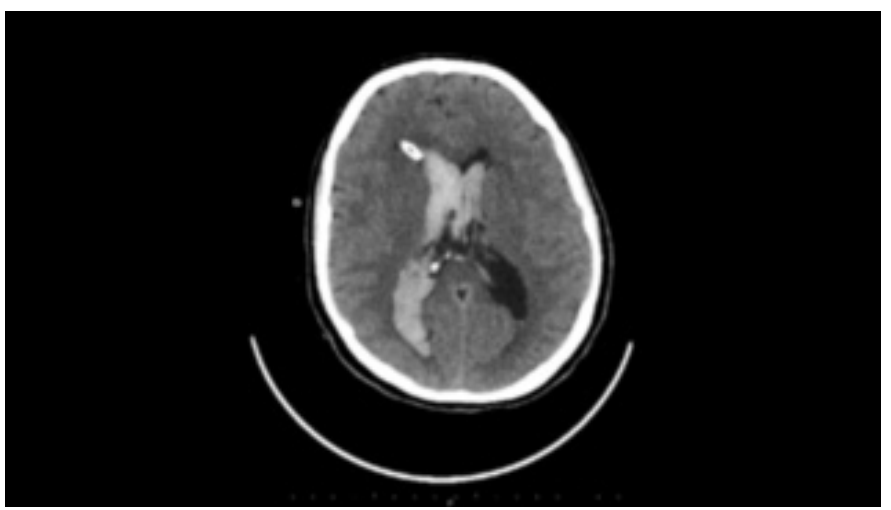

Figure 3. Brain computed tomography image showing the shunt placement and hemorrhage region after brain surgery

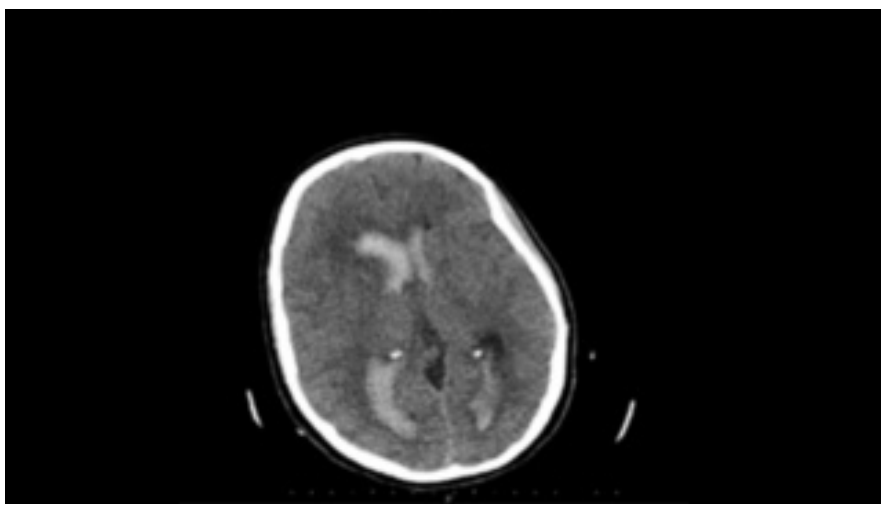

Figure 4. Brain computed tomography image showing decreased bleeding area and increased edema
During the postoperative period, the patient was followed in the intensive care unit by administering dexamethasone $(2 \times 8$ $\mathrm{mg}$ ) and mannitol $(3 \times 150 \mathrm{mg})$. Brain computed tomography performed after the shunt surgery revealed no enlargement in the hemorrhage area or increase in the shift (Figure 3).

On day three of neurosurgery, the patient regained consciousness, had a GCS score of 10, and was extubated. Mannitol dose was reduced, and the treatment was terminated on day five of neurosurgery. The shunt was removed, and her consciousness and motor functions returned to completely normal. On the day after shunt removal, the patient underwent brain computed tomography again because of confusion and decreased motor functions. The area of the hemorrhage decreased, but brain edema developed (Figure 4). Mannitol treatment was started again, and dexamethasone treatment was continued. Subsequently, confusion and motor dysfunction improved, and the treatment was continued in the clinic. The course of COVID-19 regressed with a GCS score of 10, and the patient was followed up in the inpatient service.

\section{Discussion}

Some patients with COVID-19 diagnosed with ICH have one or more of the identified risk factors for $\mathrm{ICH}$. However, the diagnosis of ICH in patients with COVID-19 who do not have any risk factor and have characteristics different from the patients with ICH with or without COVID-19 has raised doubts related to severe acute respiratory syndrome-Coronavirus-2 (SARS-CoV-2) potentially being a primary cause of $\mathrm{ICH}^{[7]}$.

Initially, we assumed that SARS-CoV-2 is neurotrophic and can cause overexpression of angiotensin-converting enzyme 2 (ACE2 ), thus invading and directly damaging cerebral blood vessels ${ }^{[8]}$. This assumption has been reinforced by the detection of viral particles in both the endothelium and cerebrospinal fluid ${ }^{[9]}$.

Previously, reduced ACE-2 levels were reported to be correlated with hypertension development ${ }^{[10]}$. Emergence of hypertension in patients with COVID-19 with or without a history of hypertension can be explained by the fact that decreased angiotensin-2 levels induce ACE-2 expression ${ }^{[11]}$. Another condition that can cause ICH in some patients with COVID-19 may be the excessive inflammatory response created by the virus ${ }^{[12]}$, leading to endothelial damage as well as arterial wall hypoxia and hemorrhage due to thrombotic microangiopathy ${ }^{[13]}$.

Previous studies examining patients with COVID-19 with ICH have reported that most patients were male, were aged $>30$ years, and had comorbid risk factors such as hypertension, diabetes mellitus, obesity, chronic artery disease, hypertriglyceridemia, congestive heart failure, sleep apnea syndrome, and autoimmune diseases ${ }^{[14]}$. Our patient had no risk factors for $\mathrm{ICH}_{\text {, except for }}$ 
pregnancy. The most common type of $\mathrm{ICH}$ in patients with COVID-19 is IPH with an involvement of a single hemisphere $(62.6 \%)$, followed by subarachnoid hemorrhage (15.0\%), subdural hemorrhage (11.6\%), and intraventricular hemorrhage $(1.4 \%)^{[114]}$. Cerebral lobes $(93.5 \%)$ are the most common sites of hemorrhage in patients with IPH. Other regions include the basal ganglia (5.4\%) and cerebellum (1.1\%). Our patient had IPH that expanded into the ventricle.

For patients with COVID-19, the initial reason for hospitalization may be neurological symptoms. Sometimes, they are admitted with normal respiratory complaints but ICH develops within the first month of presentation ${ }^{[14]}$. Our patient at term pregnancy had early stage ICH when she had come to the hospital because of ruptured membranes. Had our patient been a pregnant woman who was not diagnosed with COVID-19 and was followed at home, the first complaint upon hospitalization due to COVID-19 might have been the neurological symptoms.

The development of hypertension, excessive release of inflammation precursors, and cytokine storm can be considered the main cause of the later development of $\mathrm{ICH}$ in patients with COVID-19 ${ }^{[10]}$. Our patient did not have hypertension before and after delivery, and no symptoms such as respiratory distress, tachypnea, and fever suggesting hyperinflammation were observed. Therefore, our results suggest that the ICH is directly related to the mechanism based on the increase in angiotensin-2 as a result of endothelial damage caused by the virus and subsequent decrease in ACE-2 expression ${ }^{[12]}$.

A previous study suggested that anticoagulant treatment increases $\mathrm{ICH}$ development five times in patients with COVID-19 ${ }^{[15]}$, whereas another study suggested that although anticoagulant treatment increases $\mathrm{ICH}$ risk, patients with COVID-19 are prone to ICH even without anticoagulant treatment ${ }^{[16]}$. Anticoagulant treatment is used in the postpartum period because of the increased risk of thrombosis during pregnancy ${ }^{[17]}$. The diagnosis of COVID-19 in pregnant women reinforces the indication for anticoagulant treatment. In our case, the patient was receiving low-dose anticoagulant treatment.

\section{Conclusion}

In conclusion, ICH was observed in the postpartum period in a pregnant patient with COVID-19 who had no risk factors other than pregnancy, without exacerbating the clinical course of the disease. We believe that ICH development was primarily related to the direct effect of the virus. We also believe that pregnant women with COVID-19 should, therefore, be monitored closely in the postpartum period.

\section{Ethics}

Informed Consent: Consent form was filled out by all participants.

Peer-review: Externally and internally peer-reviewed.

\section{Authorship Contributions}

Surgical and Medical Practices: M.Ş., Concept: M.C., Design: M.C., Data Collection or Processing: M.Ş., Analysis or Interpretation: M.Ş., Literature Search: M.C., Writing: M.Ş.

Conflict of Interest: No conflict of interest was declared by the authors.

Financial Disclosure: The authors declared that this study received no financial support.

\section{References}

1. Tan YK, Goh C, Leow AST, Tambyah PA, Ang A, Yap ES, Tu TM, Sharma VK, Yeo LLL, Chan BPL, Tan BYO. COVID-19 and ischemic stroke: a systematic review and meta-summary of the literature. J Thromb Thrombolysis. 2020;50:58795.

2. Dogra S, Jain R, Cao M, Bilaloglu S, Zagzag D, Hochman S, Horwitz L, Galetta S, Berger J. Hemorrhagic stroke and anticoagulation in COVID-19. J Stroke Cerebrovasc Dis. 2020;29:104984.

3. Altschul DJ, Unda SR, de La Garza Ramos R, Zampolin R, Benton J, Holland R, Fortunel A, Haranhalli N. Hemorrhagic presentations of COVID-19: Risk factors for mortality. Clin Neurol Neurosurg. 2020;198:106112.

4. Al-Olama M, Rashid A, Garozzo D. COVID-19-associated meningoencephalitis complicated with intracranial hemorrhage: a case report. Acta Neurochir (Wien). 2020;162:1495-9.

5. Bateman BT, Schumacher HC, Bushnell CD, Pile-Spellman J, Simpson LL, Sacco RL, Berman MF. Intracerebral hemorrhage in pregnancy: frequency, risk factors, and outcome. Neurology. 2006;67:424-9.

6. Kadir RA, Kobayashi T, Iba T, Erez O, Thachil J, Kazi S, Malinowski AK, Othman M. COVID-19 coagulopathy in pregnancy: Critical review, preliminary recommendations, and ISTH registry-Communication from the ISTH SSC for Women's Health. J Thromb Haemost. 2020;18:3086-98.

7. Beyrouti R, Best JG, Chandratheva A, Perry RJ, Werring DJ. Characteristics of intracerebral haemorrhage associated with COVID-19: a systematic review and pooled analysis of individual patient and aggregate data. J Neurol. 2021:1-11.

8. Sardu C, Gambardella J, Morelli MB, Wang X, Marfella R, Santulli G. Hypertension, thrombosis, kidney failure, and diabetes: is covid-19 an endothelial disease? a comprehensive evaluation of clinical and basic evidence. J Clin Med. 2020;9:1417.

9. Baig AM, Khaleeq A, Ali U, Syeda H. Evidence of the COVID-19 Virus Targeting the CNS: Tissue Distribution, Host-Virus Interaction, and Proposed Neurotropic Mechanisms. ACS Chem Neurosci. 2020;11:995-8.

10. Alenina N, Bader M. ACE2 in Brain Physiology and Pathophysiology: Evidence from Transgenic Animal Models. Neurochem Res. 2019;44:1323-9.

11. Silhol F, Sarlon G, Deharo JC, Vaïsse B. Downregulation of ACE2 induces overstimulation of the renin-angiotensin system in COVID-19: should we block the renin-angiotensin system? Hypertens Res. 2020;43:854-6. 
12. Fatehi $P$, Hesam-Shariati $N$, Abouzaripour M, Fathi F, Hesam Shariati MB. Acute Ischemic and Hemorrhagic Stroke and COVID-19: Case Series. SN Compr Clin Med. 2020:1-6.

13. Martin JF, Booth RF, Moncada S. Arterial wall hypoxia following thrombosis of the vasa vasorum is an initial lesion in atherosclerosis. Eur J Clin Invest. 1991;21:355-9.

14. Cheruiyot I, Sehmi $P$, Ominde B, Bundi $P$, Mislani M, Ngure B, Olabu $B$, Ogeng'o JA. Intracranial hemorrhage in coronavirus disease 2019 (COVID-19) patients. Neurol Sci. 2021;42:25-33.

15. Melmed KR, Cao M, Dogra $S$, Zhang R, Yaghi $S$, Lewis A, Jain R, Bilaloglu S, Chen J, Czeisler BM, Raz E, Lord A, Berger JS, Frontera JA. Risk factors for intracerebral hemorrhage in patients with COVID-19. J Thromb Thrombolysis. 2021;51:953-60.

16. Al Saiegh $F_{1}$ Ghosh $R$, Leibold A, Avery MB, Schmidt RF, Theofanis $T$, Mouchtouris N, Philipp L, Peiper SC, Wang ZX, Rincon F, Tjoumakaris $\mathrm{SI}$, Jabbour $\mathrm{P}$, Rosenwasser RH, Gooch MR. Status of SARS-CoV-2 in cerebrospinal fluid of patients with COVID-19 and stroke. J Neurol Neurosurg Psychiatry. 2020;91:846-8.

17. Fogerty AE. Challenges of anticoagulation therapy in pregnancy. Curr Treat Options Cardiovasc Med. 2017;19:76. 